\title{
Antiproliferative and Apoptotic Effects of Angelicin in Highly Invasive Prostate Cancer Cells
}

\author{
Qing Wang ${ }^{1}$, You-Pei Wang ${ }^{2}$, Hong Lin ${ }^{3}$, Li-Qing Zhang ${ }^{4}$, Ling-Jian $\mathrm{Wu}^{5}$ and \\ Ling-Xia Pang ${ }^{1 *}$ \\ ${ }^{1}$ Function Experiment Teaching Center, Department of Laboratory. The Affiliated Eye Hospital of Wenzhou Medical University, \\ Wenzhou 325000, ${ }^{2}$ Zhejiang Provincial Key Laboratory of Medical Genetics, ${ }^{3}$ Wenzhou Medical University, Wenzhou 325035 , \\ ${ }^{4}$ Operating Room, The First Affiliated Hospital, ${ }^{5}$ Department of Dermatological, The First Affiliated Hospital of Wenzhou Medical \\ University, Wenzhou, 325000, China
}

*For correspondence: Email: panglx35@gmail.com; Tel/Fax: 0086-577-86689885

\begin{abstract}
Purpose: To demonstrate the anti-proliferative activity of angelicin against human prostate cancer (PC3) cells and to evaluate its mechanism

Methods: MTT (3-(4, 5-dimethylthiazol-2-yl)-2, 5-diphenyltetrazolium bromide) assay was used to assess the anticancer activity (growth inhibition) of angelicin in PC-3 cells. Fluorescence microscopy using Hoechst 33258 staining and inverted phase microscopy was employed to evaluate the effect of angelicin on nuclear morphology. Flow cytometry, using propidium iodide, was employed to study cell cycle-related effects of angelicin. Apoptosis induction by angelicin was examined by annexin V/PI assay.

Results: Angelicin induced potent growth inhibitory effects in human prostate cancer (PC-3) cells in a dose-dependent manner. Angelicin-treated cells exhibited chromatin condensation which implied an early apoptotic event. Inverted phase microscopy revealed that reduction of cell population occurred with increase in the angelicin dose. Flow cytometry results showed that angelicin induced cell cycle arrest in the sub-G1 phase. Angelicin induced both early and late apoptosis in PC-3 cells following a dose-dependent pattern.

Conclusion: Angelicin inhibits the growth of PC-3 human prostate cancer cells in vitro by inducing early and late apoptosis, cell cycle arrest and chromatin condensation.
\end{abstract}

Keywords: Angelicin, Coumarin, Prostate cancer, Anticancer activity, Apoptosis, Cell cycle arrest, Chromatin condensation, Flow cytometry

Tropical Journal of Pharmaceutical Research is indexed by Science Citation Index (SciSearch), Scopus, International Pharmaceutical Abstract, Chemical Abstracts, Embase, Index Copernicus, EBSCO, African Index Medicus, JournalSeek, Journal Citation Reports/Science Edition, Directory of Open Access Journals (DOAJ), African Journal Online, Bioline International, Open-J-Gate and Pharmacy Abstracts

\section{INTRODUCTION}

Prostate cancer is the development of cancer in the prostate, a gland in the male reproductive system. Most prostate cancers are slow-growing; however, some grow relatively fast. The cancer cells may spread from the prostate to other parts of the body, particularly the bones and lymph nodes. In the advanced stages of this cancer, the symptoms may include blood in the urine, pain in the pelvis, back or when urinating and difficulty in urinating [1,2]. Prostate cancer (PC) is the principal cause of new cancer cases and the second most common cause of cancer-related deaths in men in USA [3]. Prevalence rate for clinical prostate cancer in Western men are almost 40 times higher than those for Asian men. The regular treatment opportunities for prostate 
cancer comprise of surgery and radiotherapy, but these treatment regimens are loaded with severe side-effects. Plant-based drugs may provide better treatment options by preventing or slowing down disease progression. About $40-45 \%$ of patients suffering from prostate cancer use traditional complementary and alternative medicine (usually plant based) as an additional therapy $[4,5]$.

Since limited treatment regimens are available for highly invasive prostate cancer and loaded with deleterious side-effects, however the complementary and alternative medicine may provide better treatment options by inhibiting or slowing down disease progression. According to a recent survey, around $30-40 \%$ of patients suffering from prostate cancer use complementary and alternative medicine as an additional therapy our objective was to focus on a plant-based coumarin, angelicin which is actually a furanocoumarin we evaluated the antiproliferative effect of angelicin against highly invasive human prostate cancer (PC3) cells. The effect of furanocoumarin on apoptosis, cell cycle phase distribution and cell migration was studied. Angelicin showed a potent growth inhibitory effect against these cancer cells (Fig. 1). The number of living healthy cells decreased dramatically with the increase in the concentration of angelicin with an $\mathrm{IC}_{50}$ value of $65.2 \mu \mathrm{M}$ after the cells were exposed to angelicin for $48 \mathrm{~h}$.

\section{EXPERIMENTAL}

\section{Drugs and reagents}

Angelicin was purchased from Sigma Aldrich (St. Louis, MO, USA). It was dissolved to a concentration of $50 \mathrm{mM}$ in $100 \%$ dimethyl sulfoxide (DMSO) as a stock solution and stored at $20{ }^{\circ} \mathrm{C}$. The final DMSO concentrations used in the present study were $\leq 0.1 \%$.

\section{Cell line, culture conditions and angelicin treatment}

Human prostate cancer (PC-3) cell line was purchased from Guangdong Medical College (Zhanjiang, China). The cells were cultured in RPMI 1640 (Gibco BRL, Grand Island, NY, USA), supplemented with $10 \%(\mathrm{v} / \mathrm{v})$ fetal bovine serum (Gibco BRL), penicillin $100 \mathrm{U} / \mathrm{mL}$ and streptomycin $100 \mathrm{U} / \mathrm{mL}$ and maintained in a humidified atmosphere of $95 \%$ air and $5 \% \mathrm{CO}_{2}$ at $37{ }^{\circ} \mathrm{C}$. When the proliferation of the cells was $70-80 \%$, the cells were treated with various concentrations of angelicin $(5,25,50,75$ and $100 \mu \mathrm{M})$ for $48 \mathrm{~h}$.

\section{MTT assay for cell viability}

PC-3 cell density was adjusted to $2 \times 10^{5}$ cells per $100 \mu \mathrm{L}$. Cells were seeded onto 96 well plates, which were placed in an incubator overnight to allow for attachment. The cells were pretreated with $5,25,50,75$ and $100 \mu \mathrm{M}$ angelicin for $48 \mathrm{~h}$ and MTT was then dissolved to a concentration of $5 \mathrm{mg} / \mathrm{mL}$ in assay medium. A total of $20 \mu \mathrm{L}$ MTT solution was transferred to each well to yield a final volume of $120 \mu \mathrm{l} /$ well. Plates were incubated for $4 \mathrm{~h}$ at $37{ }^{\circ} \mathrm{C}$ in $5 \%$ $\mathrm{CO}_{2}$. Following incubation, supernatants were removed and $150 \mu \mathrm{L}$ DMSO was added. Plates were then placed on an orbital shaker for $10 \mathrm{~min}$ and the absorbance was recorded using the ELISA plate reader (PerkinEImer, Inc, Waltham, MA, USA) at $595 \mathrm{~nm}$.

\section{Evaluation of angelicin-induced cell apoptosis}

Human prostate cancer cells which were grown on coverslips in 12-well plates were exposed to different concentrations $(0,25,50$ and 100) of angelicin for $48 \mathrm{~h}$, then incubated with Hoechst 33258 (Hoechst Staining Kit, Beyotime, China). Fluorescence microscopy was employed to detect and measure cell shape captured from different random visual fields. The ratio of apoptotic cells to total cell number was calculated.

\section{Inverted light microscopy}

PC-3 cells were seeded in 6 -well plates at $2 \times$ $10^{4}$ cells per well in $5 \mathrm{~mL}$ of complete growth medium, incubated for $24 \mathrm{~h}$ and treated with angelicin at various concentrations $(0,25,50$ and $100 \mu \mathrm{M}$ ). Control cells treated with $0.1 \%$ DMSO alone were also included. The morphological changes were observed under an inverted light microscope (Olympus, Center Valley, PA, USA) after $48 \mathrm{~h}$.

\section{Determination of the effect of angelicin on cell cycle arrest in PC-3 cells}

PC-3 cells $\left(1 \times 10^{6}\right.$ cells $\left./ \mathrm{mL}\right)$ were seeded into each well of 6-well plates and incubated for $24 \mathrm{~h}$ for cell attachment and recovery. The cells were treated with different concentrations $(0,25,50$ and $100 \mu \mathrm{M}$ ) of angelicin. Untreated cells (control) were also incorporated. After incubation for $24 \mathrm{~h}$, the cells were harvested and fixed with ice-cold $70 \%$ ethanol $(2 \mathrm{~mL})$ at $-20{ }^{\circ} \mathrm{C}$ for $1.3 \mathrm{~h}$ Prior to analysis, the cells were washed with cold 
PBS and re-suspended in $400 \mu \mathrm{L}$ of PBS, $50 \mu \mathrm{L}$ $\mathrm{PI}$ and $50 \mu \mathrm{L}$ RNase A. The DNA contents were recorded by a flow cytometer (Becton Dickinson) equipped with Cell Quest software.

\section{Annexin V-propidium iodide assay}

Annexin V-FITC Apoptosis Detection Kit (BD Biosciences) was utilized for evaluating the mode of cell death induced by angelicin (apoptotic or necrotic cell death). The PC-3 cells $\left(1 \times 10^{6}\right.$ cells $/ \mathrm{mL}$ ) were seeded into each well of 6 -well plates and incubated for $24 \mathrm{~h}$ at $37^{\circ} \mathrm{C}$. The cells were treated with different concentrations $(0,25$, 50 and $100 \mu \mathrm{M}$ ) of angelicin. The untreated and treated cells were harvested and washed with cold PBS. Subsequently, the cells were mixed with $180 \mu \mathrm{L}$ of pre-diluted binding buffer containing Annexin V-FITC $(10 \mu \mathrm{L})$ and of PI (10 $\mu \mathrm{L})$ and further incubated for $15 \mathrm{~min}$ at $37^{\circ} \mathrm{C}$ in the dark. Subsequently, $200 \mu \mathrm{L}$ of binding buffer was added into each tube. The percentage of cell undergoing apoptosis and necrosis was quantified using a flow cytometer (Becton Dickinson, Franklin Lakes, NJ, USA) equipped with Cell Quest software within $2 \mathrm{~h}$.

\section{Statistical analysis}

Data are presented as mean \pm standard deviation ( $S D, n=6)$. Analysis of variance (ANOVA) was conducted using SPSS (version
20 SPSS Inc, Chicago, DE USA) to evaluate significant difference. Subsequently, the significance of the difference was evaluated using Dunnet test, and $p<0.05$ was considered significant.

\section{RESULTS}

\section{Antiproliferative activity of angelicin against human prostate cancer (PC-3) cells}

Angelicin showed a potent growth inhibitory effect against these cancer cells (Fig. 1). The number of living healthy cells decreased dramatically with the increase in the concentration of angelicin with an $\mathrm{IC}_{50}$ value of $65.2 \mu \mathrm{M}$ after the cells were exposed to angelicin for $48 \mathrm{~h}$.

\section{Detection of angelicin-induced apoptosis by fluorescence microscopy}

Angelicin-treated cells exhibited chromatin condensation or dense staining fragmentation (apoptotic bodies), which implied an early apoptotic event. The induced apoptosis seemed to follow concentration dependence with greater apoptosis at higher angelicin doses (Fig. 2).

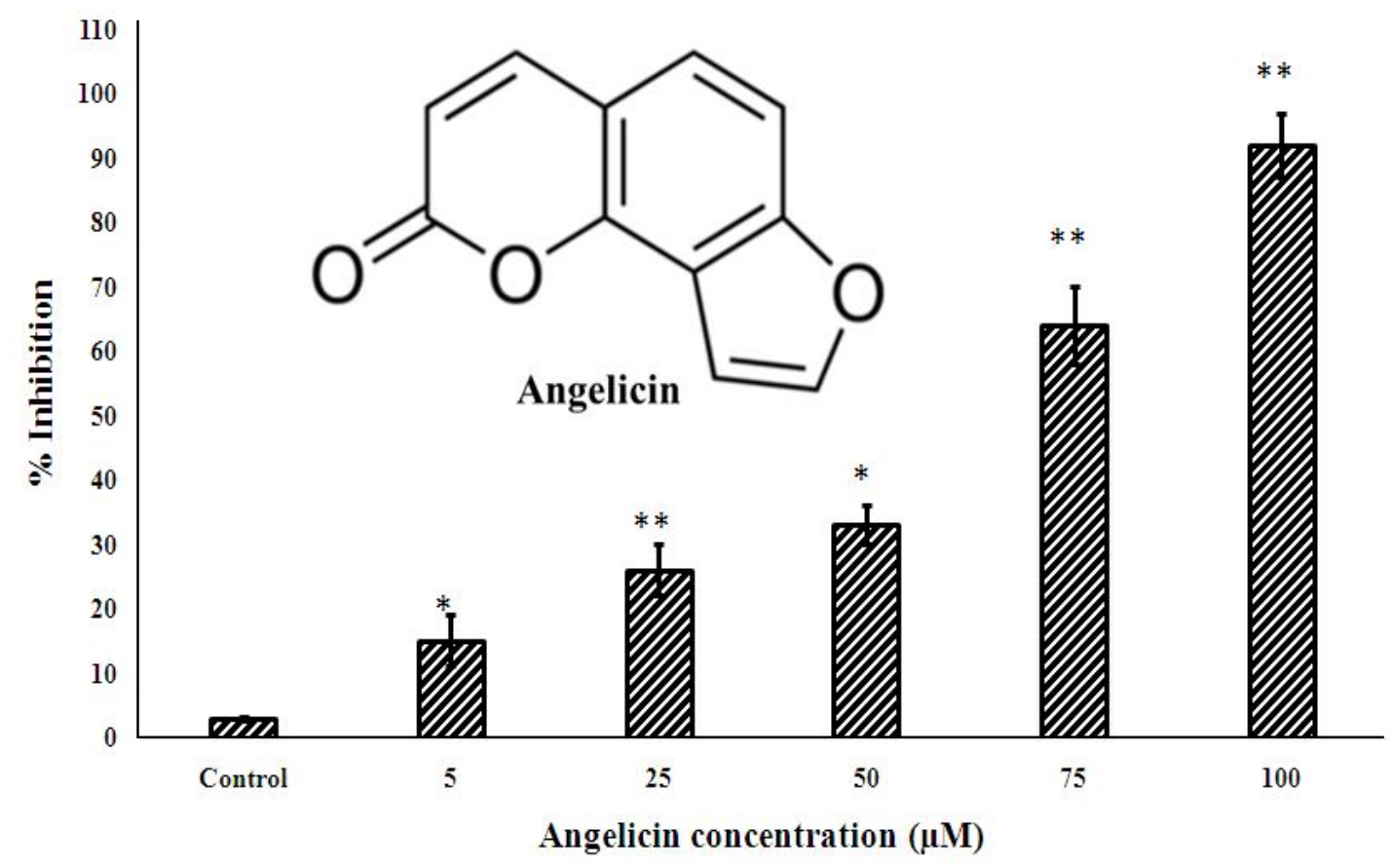

Figure 1: Effect of angelicin on the cell viability of human prostate cancer cell (PC-3) at different concentration; ${ }^{*} p<0.05$ vs. control group; ${ }^{* *} p<0.01$ vs. control group 

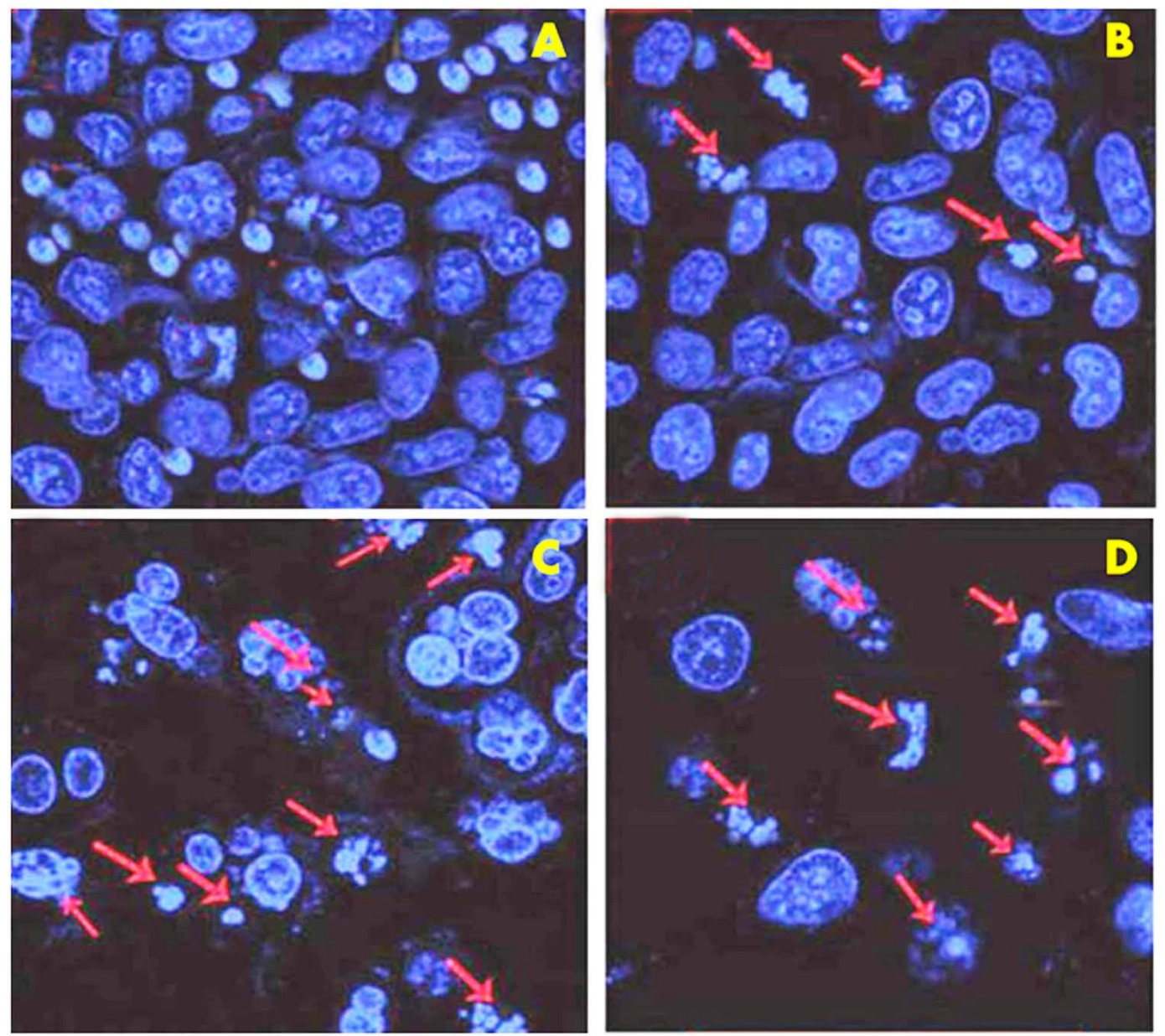

Figure 2: Morphological observation of angelicin-induced apoptosis with Hoechst 33258 staining at actual magnification $200 \times$. PC-3 cells were treated without (A) and with angelicin $25 \mu \mathrm{M}(\mathrm{B}), 50 \mu \mathrm{M}(\mathrm{C})$, and $100 \mu \mathrm{M}$ (D) for $48 \mathrm{~h}$. Red arrows represent chromatic condensation

\section{Inverted light micrographs}

The most prominent changes characteristic of apoptosis were observed in the treated cells that include the detachment of the cells from substratum, cell shrinkage, nuclear condensation, membrane blebbing as well as formation of apoptotic bodies. As revealed by inverted light microscopy, the untreated control cells were evenly distributed on the substratum. Reduction in the cell population was noted with increase in the angelicin concentration. Angelicin induced growth inhibitory effects and morphological alterations in human prostate (PC3) cancer cells (Fig $3 A-D$ ), cell shrinkage and blebbing was increased with increase in angelicin concentration.

\section{Angelicin induces cell cycle arrest in PC-3 cells}

It was observed that angelicin induced cell cycle arrest in the sub-G1 phase of the cell cycle increasing cell population of the sub-G1 phase after $48 \mathrm{~h}$ (Fig. 4). In the control group, the major cell population was found to be in the $\mathrm{G} 1$ phase $(67.12 \%)$, with a low percentage of cells in the G2/M phase. Generally, the cell cycle arrest is associated closely with apoptosis, that is, the occurrence of cell cycle arrest leads to cell apoptosis, which includes numerous signaling molecules and regulatory proteins.

\section{Apoptosis results}

The results in Fig. 5 reveal that angelicin induced both early and late apoptosis in a concentrationdependent manner (Fig 5B - D) as compared to the untreated control cells (Fig 5A). The percentage of apoptotic cells increased from 13 $\%$ in the untreated control to $25.7,64.5$ and 78.3 $\%$ in 25,50 and $100 \mu \mathrm{M}$ angelicin concentrationtreated cells, respectively. 

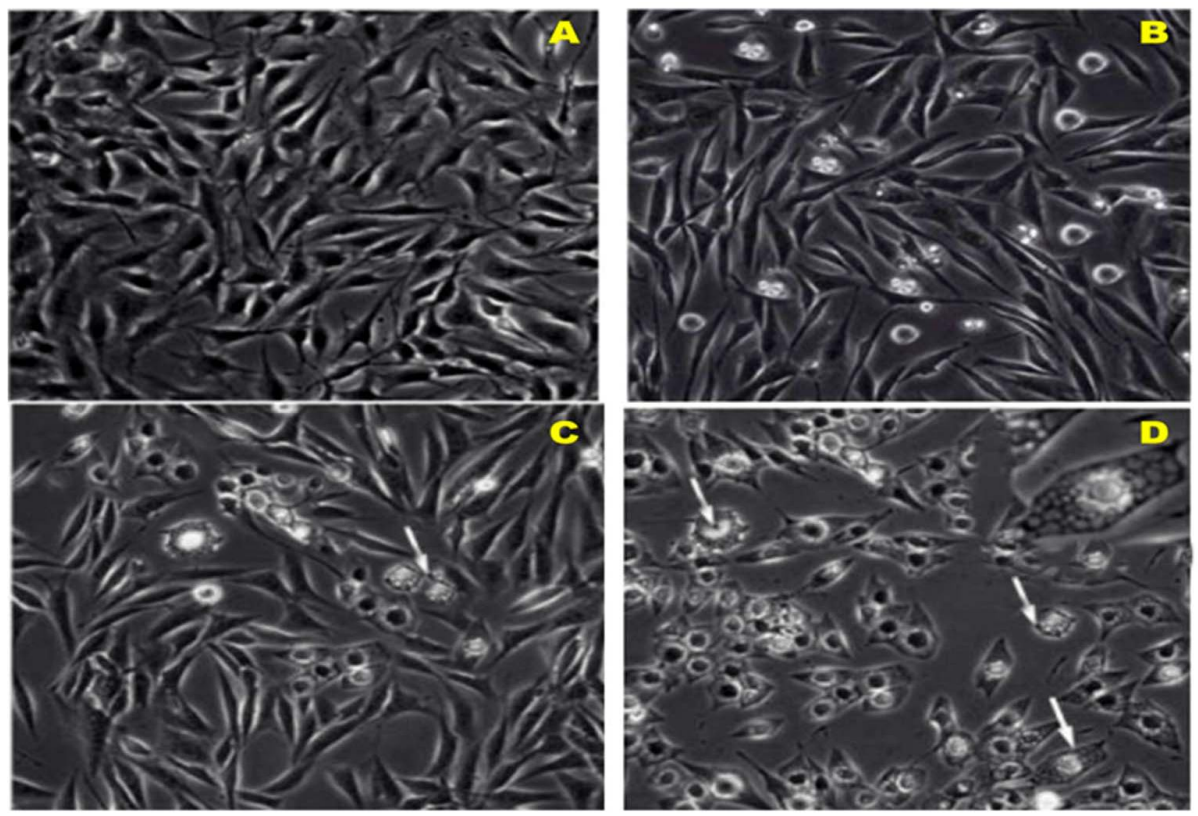

Figure 3: Angelicin-induced morphological changes in human prostate cancer (PC-3) cells as detected by inverted light microscopy (magnification X400). Cellular shrinkage and blebbing were observed in angelicintreated cells (arrows). A represents control (untreated cells), B,C and D represent effect of 25, 50 and $100 \mu \mathrm{M}$ of angelicin on cell morphology of PC-3 cells
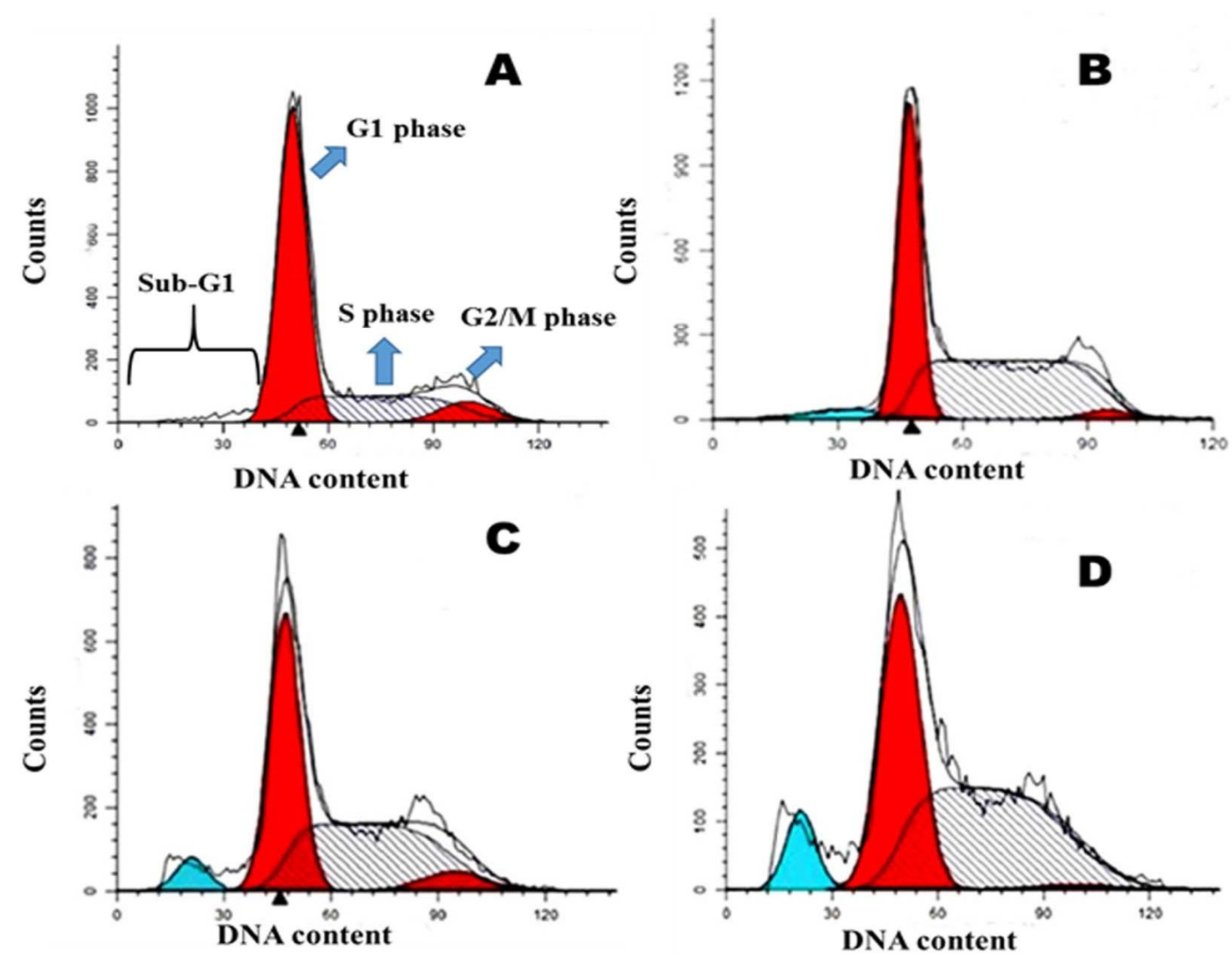

Figure 4: Angelicin induced cell cycle arrest at sub-G1 phase in human prostate cancer cells (PC-3). The PC-3 cells were subjected to $0 \mu \mathrm{M}$ (untreated, A), $25 \mu \mathrm{M}(\mathrm{B}), 50 \mathrm{Mm}(\mathrm{C})$ and $100 \mu \mathrm{M}(\mathrm{D})$ of angelicin. The cells in the sub-G1 phase (apoptotic cells) increased from A-D, with an increase in angelicin dose. The DNA histogram shows the distribution and the percentage of cells in phases of the cell cycle 

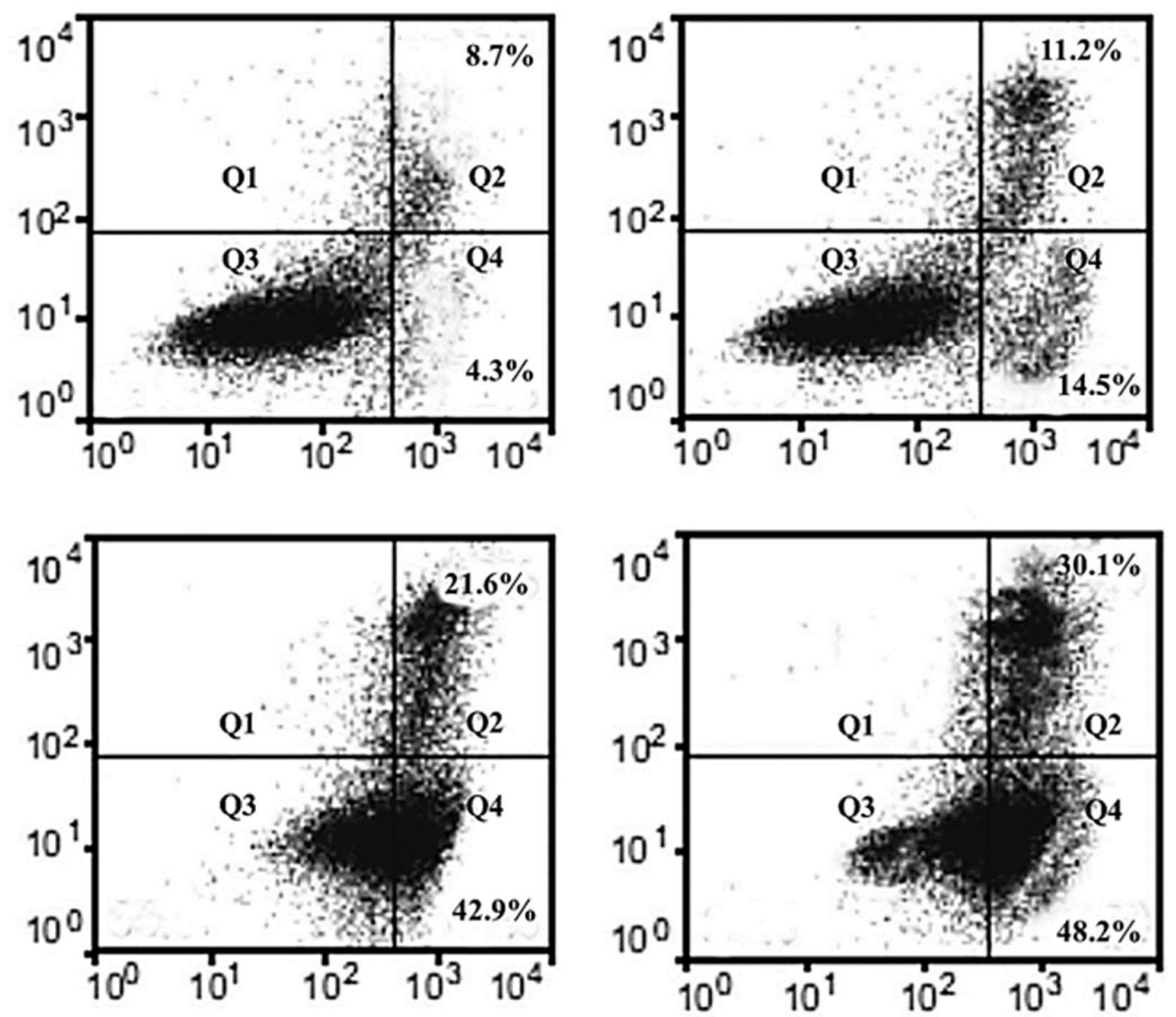

Fig 5: Apoptosis induction in human prostate (PC-3) cancer cells by angelicin. PC-3 cells were exposed to different doses of angelicin $(0,25,50$ and $100 \mu \mathrm{M})$ for $48 \mathrm{~h}$ and analyzed by flow cytometry with annexin $\mathrm{V}$ FITC/PI staining. The QI quadrant shows necrotic cells, Q2 shows late apoptotic cells, Q3 shows live cells while as Q4 shows early apoptotic cell population. The plots in the figure are representative of 5 independent experiments

\section{DISCUSSION}

Previous studies have shown that some natural chemopreventive agents can induce apoptosis of tumor cells and inhibit tumor growth, both in vitro and in vivo [6-9]. Because of their selectivity in killing tumor cells and minimal toxicity compared to conventional chemotherapies, they are becoming promising approaches for tumor treatments. Coumarins and their known metabolite, 7-hydroxy-coumarin, have been shown to have growth suppressive effect on many cancer cell lines, such as colon-carcinoma cell lines, hepatocellular carcinoma cell lines, leukemia cell lines, melanoma cell lines, renal cell carcinoma cell lines and non-small cell lung carcinoma cell lines. Auraptene, one of the coumarins, has been shown to be effective in inhibiting the development of esophageal tumors and colitis-related colon cancers in animal models [10-12]. Coumarin has also been used in a clinical trial to prevent disease recurrence in melanoma patients [13]. They can affect multiple signaling pathways, such as ERK/MAPK and
PI3K/Akt pathways, which play important roles in carcinogenesis [14-16].

In the present study, anticancer effect of angelicin-a known coumarin, was evaluated against human prostate cancer cells (PC-3) using MTT assay. Further, the underlying mechanism of the anticancer action of angelicin was demonstrated by studying the effect of this coumarin on nuclear morphology of the PC-3 cells after drug treatment. For this purpose, fluorescence and inverted phase microscopy were used. The results revealed that angelicintreated cells exhibited chromatin condensation which implied an early apoptotic event. Inverted phase microscopy revealed that reduction of cell population occurred with increase in the angelicin dose. Further flow cytometry experiment revealed that angelicin induced cell cycle arrest in the sub-G1 phase of the cell cycle. Generally, the cell cycle arrest is associated closely with apoptosis, that is, the occurrence of cell cycle arrest leads to cell apoptosis, which includes numerous signaling molecules and regulatory proteins. 


\section{CONCLUSION}

The results of this study demonstrate that angelicin, a naturally occurring coumarin, exhibits anticancer effects against PC-3 human prostate cancer cells by inducing apoptosis, chromatin condensation and cell cycle arrest. Further studies are required to develop this potent compound as a possible chemotherapeutic agent for treating prostate cancer.

\section{REFERENCES}

1. World Cancer Report 2014. World Health Organization. 2014. pp Chapter 5.11.

2. Ruddon, Raymond W. Cancer biology. 4th edn. Oxford: Oxford University Press; 2007. $p 223$.

3. Jemal A, Siegel R, Ward E, Murray $T, X u J$, Smigal $C$, Thun MJ. Cancer statistics, 2006. CA Cancer J Clin 2006; 56(2):106-130.

4. Eton D, Lepore S. Prostate cancer and health-related quality of life: a review of the literature. Psychooncology 2002; 11(4): 307-326.

5. Eisenberg DM, Davis RB, Ettner SL, Appel S, Wilkey S, Van Rompay M, Kessler RC. Trends in alternative medicine use in the United States, 1990-1997: results of a follow-up national survey. JAMA 1998; 280(18): 1569-1575.

6. Zhang $\mathrm{YH}$, Peng $\mathrm{HY}$, Xia GH, Wang MY, Han $\mathrm{Y}$. Anticancer effect of two diterpenoid compounds isolated from Annona glabra Linn. Acta Pharmacol $\operatorname{Sin} 2004 ;$ 25(7): 937-942.

7. Jung EM, Lim JH, Lee TJ, Park J-W, Choi KS, Kwon TK. Curcumin sensitizes tumor necrosis factor-related apoptosis-inducing ligand (TRAIL)-induced apoptosis through reactive oxygen species-mediated up regulation of death receptor 5 (DR5). Carcinogenesis 2005; 26(11): 1905-1913.

8. Yeh C-T, Yen G-C. Induction of Apoptosis by the Anthocyanidins through Regulation of Bcl-2 Gene and Activation of C-Jun N-Terminal Kinase Cascade in Hepatoma Cells. J Agric Food Chem 2005; 53(5): 1740-1749.

9. Weber US, Steffen B, Siegers CP. Antitumor-activities of coumarin, 7-hydroxy-coumarin and its glucuronide in several human tumor cell lines. Res Commun Mol Pathol Pharmacol 1998; 99(2): 193-206.

10. Lopez-Gonzalez JS, Prado-Garcia H, Aguilar-Cazares D, Molina-Guarneros JA, Morales-Fuentes J, Mandoki JJ. Apoptosis and cell cycle disturbances induced by coumarin and 7-hydroxycoumarin on human lung carcinoma cell lines. Lung Cancer 2004; 43(3): 275283.

11. Finn GJ, Creaven BS, Egan DA. Daphnetin induced differentiation of human renal carcinoma cells and its mediation by $p 38$ mitogen-activated protein kinase. Biochem Pharmacol 2004; 67(9): 1779-1788.

12. Kohno $H$, Suzuki R, Curini M, Epifano F, Maltese $F$, Gonzales SP, Tanaka T. Dietary administration with prenyloxycoumarins, auraptene and collinin, inhibits colitis-related colon carcinogenesis in mice. Int $J$ Cancer 2006; 118(12): 2936-2942.

13. Thornes RD, Daly L, Lynch G, Breslin B, Browne H, Browne HY, Corrigan T, Daly P, Edwards G, Gaffney $E$ et al. Treatment with coumarin to prevent or delay recurrence of malignant melanoma. J Cancer Res Clin Oncol 1994; 120: S32-34.

14. Lee SH, Park C, Jin CY, Kim GY, Moon SK, Hyun JW, Lee WH, Choi BT, Kwon TK, Yoo YH et al. Involvement of extracellular signal-related kinase signaling in esculetin induced $\mathrm{G} 1$ arrest of human leukemia U937 cells. Biomed Pharmacother 2008; 62(10): 723-729.

15. Riveiro ME, Vazquez R, Moglioni A, Gomez N, Baldi A, Davio C, Shayo C. Biochemical mechanisms underlying the pro-apoptotic activity of 7,8-dihydroxy4-methylcoumarin in human leukemic cells. Biochem Pharmacol 2008; 75(3): 725-736.

16. Goel A, Prasad AK, Parmar VS, Ghosh B, Saini N. 7,8Dihydroxy-4-methylcoumarin induces apoptosis of human lung adenocarcinoma cells by ROSindependent mitochondrial pathway through partial inhibition of ERK/MAPK signaling. FEBS Lett 2007; 581(13): 2447-2454. 